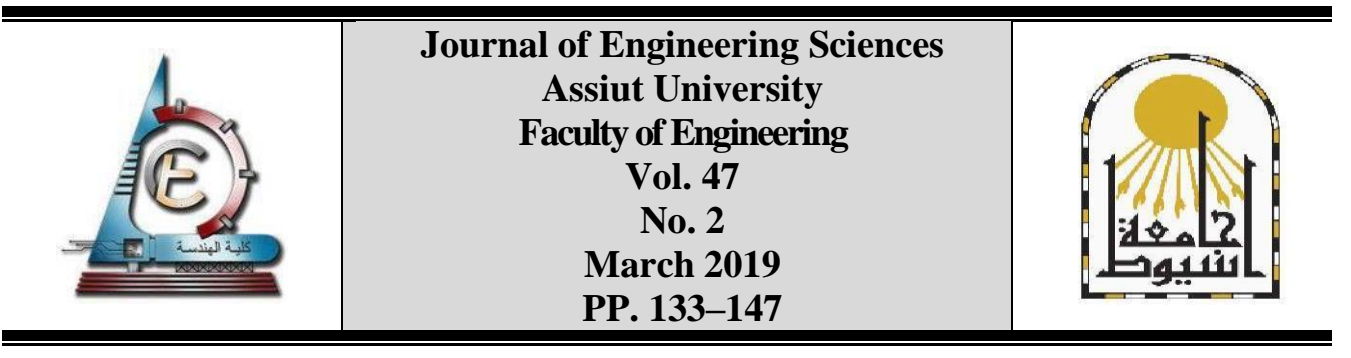

\title{
EVALUATION OF WAVE ATTENUATION BY FLEXIBLE CONTAINER BREAKWATER
}

\author{
Sherif Abdellah \\ Civil Engineering Dept., Faculty of Engineering-Port Said University, Egypt \\ Email: sherif.elsayed@eng.psu.edu.eg
}

Received 13 December 2018; Accepted 22 December 2018

\begin{abstract}
A flexible container breakwater "FCB", is made of a flexible membrane which filled with sand-water slurry. It is proposed for use in shallow water to attenuate wave energy in non-frequent storm sites and as temporary deployments, instead of costly traditional breakwaters. Experimental studies were carried out under irregular waves mainly in a wave flume and another limited runs in a wave basin. The purpose is to evaluate FCB stability criteria and wave dissipation capabilities. Filling the FCB with slurry with $40 \%$ sand was found safe enough against floatation forces. Also, It keeps the system in position under subaerial condition at $\mathrm{Hs}=1.50 \mathrm{~m} \& \mathrm{Tp}=5.5 \mathrm{~s}$ and $\mathrm{Hs}=1.9 \& \mathrm{Tp}=7.0 \mathrm{~s}$ waves according to the $\mathrm{FCB}$ bottom contact width. For higher waves, it need be moored by a belt in which the maximum total force is estimated as $2 \%$ of its net weight under subaerial conditions and $4 \%$ under submergence ratio 0.15 .
\end{abstract}

The dissipation coefficient, within the tests program, reached to $80 \%$. Finally, important parameters affecting the efficiency were discussed and its range of applications was proposed.

Keywords: Rubber breakwater, wave attenuation, temporary breakwater, flexible breakwater, Geotextile container

\section{Introduction}

In areas subjected to non-frequent moderate storm passages such as Ras Elbar, Egypt; Figure (1), and other places, conventional breakwaters such as a rubble mound; figure (2) or vertical barriers are not the proper value engineered design due to its initial cost and undesirable effects on the scenic value of beaches.

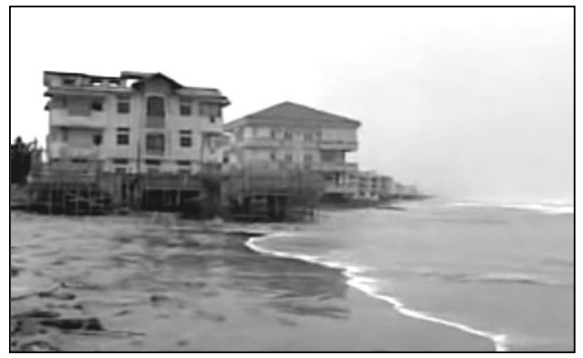

Fig. 1. Ras Elbar-Egypt winter seasonal storm surge 

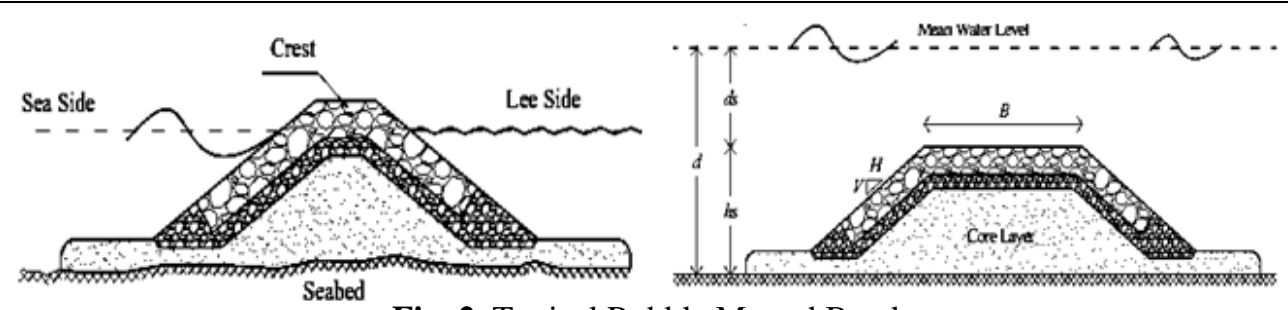

Fig. 2. Typical Rubble Mound Breakwater

Sand filled geo-bags or large sand filled containers (SFC), figure (3), for the construction of offshore structures are gaining acceptance as a cost effective method of submerged breakwater construction [1].
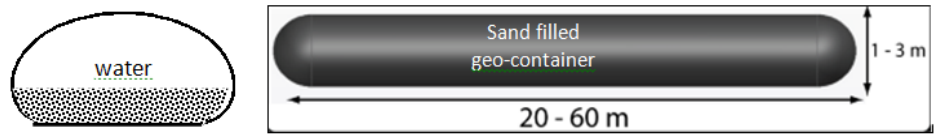

Fig. 3. Typical Sand Filled geotextile Containers (SFC)

For marine recreational projects, there is a particular need for invisible, safe and effective wave attenuation measures. Conventional submerged rigid mounds could partially meet this need if they are made wide enough with its height near to the water surface. However, they are often too massive for such applications, and breaking waves and currents in the structure vicinity could harm swimmers and small boats and jet skis. As an alternative to rigid breakwaters, for such specific applications, the author analysed a flexible breakwater made of an elastic impermeable rubber filled with water sand mixture.

The system can be inflated with seawater-sand mixture. It is expected to act as a heavy barrier against waves and storm surges. It can be deployed, and packed away compactly when not in use. Water can also be pumped out and just keep part of sand. In this case the barrier will not disturb either scenic value or boats operation in calm seasons.

[3], [5], and [6] explained and investigated the role of muddy seabed on wave attenuation. In their approach, the mud layer behaves like a flexible membrane dissipating wave energy not only due to friction, like sandy sea bed, but also due to energy lost in generating internal waves at mud surface.

[8] and [9] studied wave dissipation by a flexible mound; Fig. (4). It was found substantially different from that corresponding to a rigid model, and that a flexible mound can effectively dissipate waves even at submergence ratio (R/d; Fig. 8) greater than 0.40 .

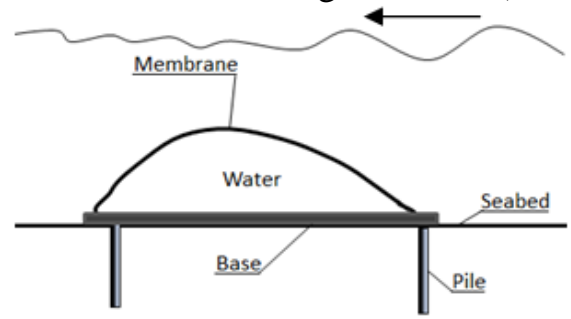

Fig. 4. Concept of flexible mound

The first objective of the present experimental study is to investigate the stability conditions of self-standing Flexible Container Breakwaters (FCBs). The second objective is to evaluate its efficiency as wave attenuation system, and understand its performance governing factors. 


\section{Model and experiments setup}

The physical model experiments were carried out at the Coastal laboratory- Research centre of Suez Canal Authority. The flume has dimensions of $(40 \mathrm{~m} \times 1.50 \mathrm{~m} \times 0.75 \mathrm{~m})$ with $0.40 \mathrm{~m}$ maximum water depth; Fig. (5). The flume is equipped with a piston type wave generator capable to generate regular and irregular waves for different spectrum types. The side walls of the flume have glass panels to allow visual monitoring of the experiments. The flume has a passive wave absorbing slope to reduce the effect of reflected waves from the paddles. Five wave gauges were used for recording the incident, reflected and transmitted waves.

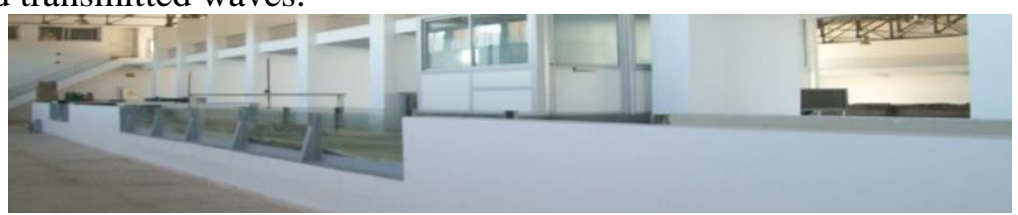

Fig. 5. Wave flume general view

Due to the wave flume limitations, the applied geometrical scale was 1:20. The flow and gravity forces were scaled following Froude scale laws. The FCB model dimensions are $1.45 \mathrm{~m}$ length and $0.35 \mathrm{~m}$ diameter. It includes two openings for water/slurry filling and emptying. Fig. (6), shows the model unit with mooring lines arrangements. The model was fabricated from $2.5 \mathrm{~mm}$ thick rubber. The material was tested in the lab to define its physical properties. Results are summarized in Table (1). The model general arrangement in the wave flume is shown in Fig. (7).
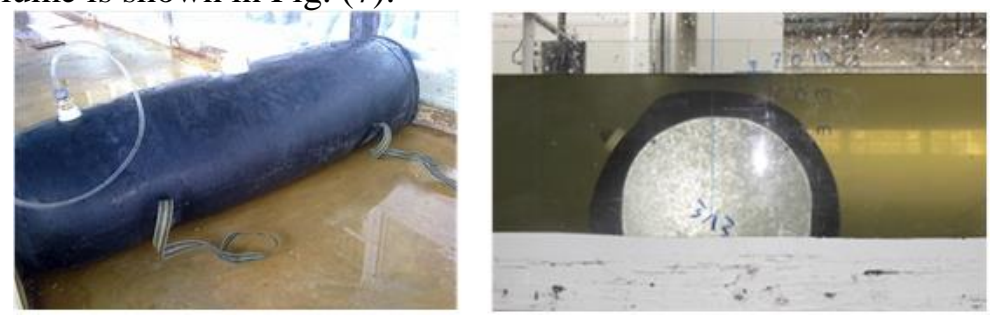

Fig. 6. FCB model unit

Table 1.

Rubber material physical parameters

\begin{tabular}{|c|c|c|c|c|}
\hline Sample\# & $\begin{array}{c}\text { Initial Thickness } \\
(\mathrm{mm})\end{array}$ & $\begin{array}{c}\text { Max. } \\
\text { elongation } \%\end{array}$ & $\begin{array}{c}\text { Final Thick. } \\
(\mathrm{mm})\end{array}$ & strength (N/mm $\left.{ }^{2}\right)$ \\
\hline 1 & 2.50 & $437 \%$ & 1.10 & 17.0 \\
\hline 2 & 2.50 & $446 \%$ & 1.10 & 23.0 \\
\hline
\end{tabular}

Fig. 7. Flume experiments general arrangement 
Because of rubber natural elasticity, the model final cross section shape is affected by the water/sand slurry volume filling the model and the flume water depth. Filling more slurry in the model caused changing in cross section dimensions. Also, increasing the water depth resulted in more side pressure on the model. In this study, we filled the model up to $98 \%$ of its normal capacity. i.e, no rubber stretching occurred due to the internal water. Under still water, the model section has $40 \mathrm{~cm}$ width $/ 30 \mathrm{~cm}$ height which was kept constant for all experimental runs; refer to figure (8). To eliminate rubber friction with the flume side walls, the model was ended with thin aluminium plates.

Three water depths were considered while carrying out experiments to represent the probable three operation conditions of the FCB as shown in figure (8) and table (2). Field wave significant heights range between 0.50 to $2.20 \mathrm{~m}$ and period range 3.50 to $7.0 \mathrm{sec}$. are modelled and applied to the wave maker.

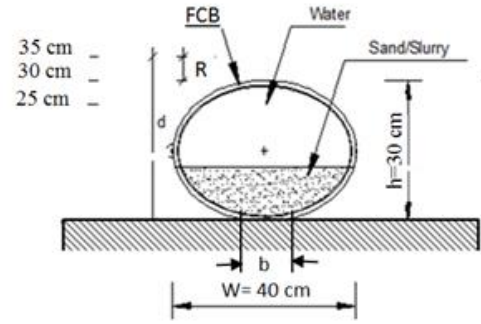

Fig. 8. The model parameters

Table 2.

FCB geometrical parameters- Model \#1

\begin{tabular}{|c|c|c|c|c|}
\hline FCB condition & $\begin{array}{c}\text { FCB cross } \\
\text { section } \\
(\mathrm{m})\end{array}$ & $\begin{array}{c}\text { Water depth; } \\
\mathrm{d}(\mathrm{m})\end{array}$ & $\begin{array}{c}\text { Relative height; } \\
\mathrm{h} / \mathrm{d}\end{array}$ & $\begin{array}{c}\text { Contact } \\
\text { width; } \mathrm{b}(\mathrm{m})\end{array}$ \\
\hline Submerged & $0.4 \times 0.3$ & 0.35 & 0.85 & 0.22 \\
\hline At Water surface & $0.4 \times 0.3$ & 0.30 & 1 & 0.22 \\
\hline subaerial condition & $0.4 \times 0.3$ & 0.25 & 1.2 & 0.22 \\
\hline
\end{tabular}

To decide the proper sand percentage in the water sand slurry, a set of initial tests has been done to check the model stability against floatation under still water and waves conditions. Sand percentage range from 20 to $40 \%$ was applied. $20 \%$ sand was safe against floatation in subaerial condition. However, under submergence condition $40 \%$ sand was necessary to be safe against floatation. Finally, we decided to apply $40 \%$ sand ratio for all the experiments; table (3). The initial model bed contact width is $22 \mathrm{~cm}$ under air conditions; i.e., about $50 \%$ of the model width. Under submerged conditions and waves conditions given in run\#3 (table-3), the model excursed from its initial location about 40 $\mathrm{cm}$ against wave propagation direction after $12 \mathrm{~min}$ period (run time); Fig. (9).

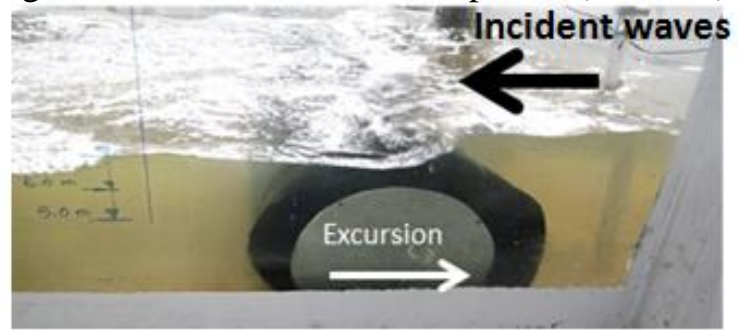

Fig. 9. FCB model under submergence condition 
To prevent the model excursion, some tests were done to install proper mooring lines. Finally, the convenient method was using two belts, one near each end, wrapping the model then, connected to $1.0 \mathrm{~mm}$ wire pass over pulleys to connect finally to digital force cells of $1.0 \mathrm{~N}$ accuracy to instantaneously record tension force in each wire.

\section{Experiments program}

All Tests were carried out for three water depths and sets of TMA wave spectrum conditions; refer table (3). Three tests were done without mooring lines and eight tests done with mooring lines. Results of the experiments were used for estimating reflection and transmission coefficients, energy dissipation, and tension force in mooring lines.

Another few runs have been done with another FCB model in a wave basin. The basin dimensions are $(22.85 \mathrm{~m} \times 52.60 \mathrm{~m} \times 1.00 \mathrm{~m})$ with maximum water depth $0.40 \mathrm{~m}$; Figs. (10) and (11). It is equipped with a piston type wave generator (DHI wave generator), with 6 hydraulically driven wave paddles capable to generate unidirectional regular and irregular waves. In this study, irregular waves (TMA spectra) were used. In this basin we tested another material where the model consists of two polyethylene compartments inside a geotextile container with a length 3.50 meters, as shown in Fig. (12).

Table 3.

Wave Parameters for Experiments (Prototype)

\begin{tabular}{|c|c|c|c|c|c|c|c|c|}
\hline \multirow{2}{*}{ Run \# } & \multicolumn{2}{|c|}{$\mathrm{d}=5.0 \mathrm{~m}$} & \multicolumn{2}{c|}{$\mathrm{d}=6.0 \mathrm{~m}$} & \multicolumn{2}{c|}{$\mathrm{d}=7.0 \mathrm{~m}$} & \multicolumn{2}{c|}{ Mooring Condition } \\
\cline { 2 - 9 } & $\mathrm{Hs}(\mathrm{m})$ & $\mathrm{Tp}(\mathrm{s})$ & $\mathrm{Hs}(\mathrm{m})$ & $\mathrm{Tp}(\mathrm{s})$ & $\mathrm{Hs}(\mathrm{m})$ & $\mathrm{Tp}(\mathrm{s})$ & $\begin{array}{c}\text { Non } \\
\text { moored }\end{array}$ & Moored \\
\hline 1 & 0.5 & 4 & 0.5 & 4 & 0.5 & 4 & $\sqrt{ }$ & $\sqrt{ }$ \\
\hline 2 & 0.7 & 3.5 & 0.7 & 3.5 & 0.7 & 3.5 & $\sqrt{ }$ & $\sqrt{ }$ \\
\hline 3 & 1.5 & 5.5 & 1.5 & 5.5 & 1.5 & 5.5 & $\sqrt{ }$ & $\sqrt{ }$ \\
\hline 4 & 1.6 & 5 & 1.6 & 5 & 1.6 & 5 & & $\sqrt{ }$ \\
\hline 5 & 1.8 & 5.5 & 1.8 & 5.5 & 1.8 & 5.5 & & $\sqrt{ }$ \\
\hline 6 & 1.9 & 7.0 & 1.9 & 7.0 & 1.9 & 7.0 & & $\sqrt{ }$ \\
\hline 7 & 1.9 & 6.5 & 2.1 & 6.5 & 2.2 & 6.5 & & $\sqrt{ }$ \\
\hline 8 & 1.0 & 5.5 & 1.0 & 5.5 & 1.0 & 5.5 & & $\sqrt{ }$ \\
\hline
\end{tabular}

The model was tested in two conditions; filled with water only under sub-aerial condition and filled with $40 \%$ sand for submerged conditions (it has elliptical shape; $0.90 / 0.30 \mathrm{~m})$. These dimensions are considered suitable to perform all experiments for different water depths and wave conditions using undistorted (1:20) geometrical scale Froude model. The model footprint area is $3.45 \times 0.85 \mathrm{~m}$ (in air). It will develop friction resistance and is affected by the water depth in the basin. In all cases, no mooring lines were used. Three water depths are considered during the experiments as shown in table (4).

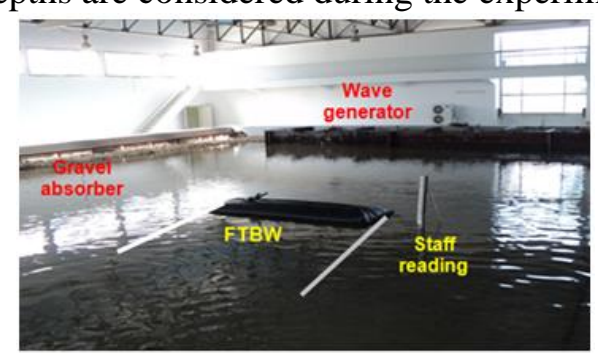

Fig. 10. The wave basin 


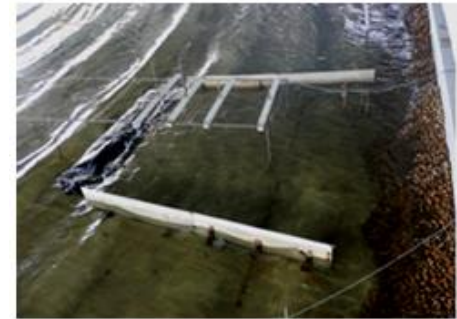

Fig. 11. The model in basin with guide plates

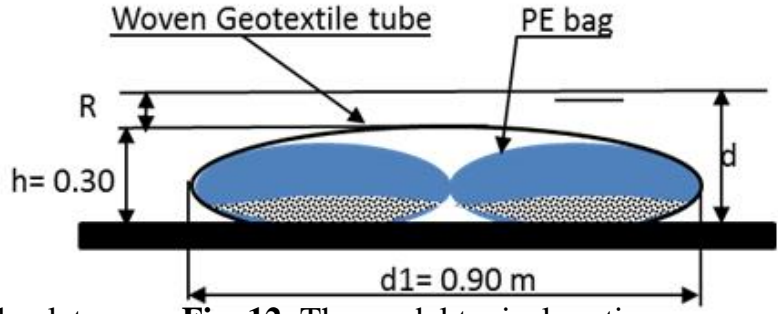

Fig. 12. The model typical section

Table 4.

Prototype FCB geometrical parameters- Model \#2

\begin{tabular}{|c|c|c|c|c|c|}
\hline FCB condition & $\begin{array}{c}\text { FCB cross } \\
\text { section } \\
(\mathrm{m})\end{array}$ & $\begin{array}{c}\text { Water } \\
\text { depth; } \\
\mathrm{d}(\mathrm{m})\end{array}$ & $\begin{array}{c}\text { Relative } \\
\text { height; } \\
\mathrm{h} / \mathrm{d}\end{array}$ & $\begin{array}{c}\text { Submergence } \\
\mathrm{R} / \mathrm{d}\end{array}$ & $\begin{array}{c}\text { Contact } \\
\text { width; } \\
\mathrm{b}(\mathrm{m})\end{array}$ \\
\hline Submerged & $0.9 \times 0.3$ & 0.35 & 0.85 & 0.15 & 0.85 \\
\hline At Water surface & $0.9 \times 0.3$ & 0.30 & 1 & 0 & 0.85 \\
\hline subaerial condition & $0.9 \times 0.3$ & 0.25 & 1.2 & -0.2 & 0.85 \\
\hline
\end{tabular}

The waves characteristics are represented by TMA spectrum. Their directions were kept perpendicular to the model in all tests. Table (5) summarizes the tested wave parameters for different water depths.

\section{Table 5.}

Tested Wave and water depth conditions (Prototype values)

\begin{tabular}{|c|c|c|c|c|c|}
\hline \multicolumn{5}{|c|}{ Wave Conditions for different water depths } \\
\hline \multicolumn{2}{|c|}{$\mathrm{d}=5.0 \mathrm{~m}$} & \multicolumn{2}{c|}{$\mathrm{d}=6.0 \mathrm{~m}$} & \multicolumn{2}{c|}{$\mathrm{d}=7.0 \mathrm{~m}$} \\
\hline Hs (m) & $\begin{array}{c}\text { Tp } \\
(\mathrm{s})\end{array}$ & $\mathrm{Hs}(\mathrm{m})$ & $\begin{array}{c}\mathrm{Tp} \\
(\mathrm{s})\end{array}$ & $\mathrm{Hs}(\mathrm{m})$ & $\mathrm{Tp}(\mathrm{s})$ \\
\hline 1.5 & 5.5 & 1.5 & 5.5 & 1.5 & 5.5 \\
\hline 1.9 & 7.0 & 1.9 & 7.0 & 1.9 & 7.0 \\
\hline
\end{tabular}

\section{Analysis and discussion}

Wave transmission and reflection were measured to evaluate FCB wave attenuation efficiency. The analysis of experiments output data revealed some important results and lead to more understanding of the performance of such breakwater under waves.

The results could be concluded as follows; the stability under stand-alone conditions was affected by the bag material as it controls its deformation, contact area, and friction with the seabed. For subaerial condition the free seating FCB was stable under all experimental wave data (no excursion occurred). There were some radiation waves, generated by the bag's motion. In addition to waves interaction with the structure and wave breaking, radiated waves might participate in wave energy dissipation, [9]. The scale of bag motion was affected directly by the material type under the same wave conditions. The second model with outer geotextile material showed better stability than the first rubber one. The impact of wave period on energy dissipation was different for the two models due the nature of bag geometric deformation shape. The effectiveness of wave dissipation by FCB model and its stability was compared to conventional breakwaters literature under similar water conditions. 


$$
\begin{aligned}
& \mathrm{K}_{\mathrm{r}}=\mathrm{H}_{\mathrm{r}} / \mathrm{H}_{\mathrm{i}} \\
& \mathrm{K}_{\mathrm{t}}=\mathrm{H}_{\mathrm{t}} / \mathrm{H}_{\mathrm{i}} \\
& \mathrm{E}_{\text {total }}=\mathrm{E}_{\mathrm{r}}+\mathrm{E}_{\mathrm{d}}+\mathrm{E}_{\mathrm{t}} \\
& \mathrm{E}_{\mathrm{i}}=\mathrm{E}_{\text {total }}
\end{aligned}
$$

The wave reflection coefficient $\left(\mathrm{K}_{\mathrm{r}}\right)$, the dissipation coefficient $\left(\mathrm{K}_{\mathrm{d}}\right)$ and the transmission coefficient $\left(\mathrm{K}_{\mathrm{t}}\right)$ are correlated by the relationship:

$$
\mathrm{K}_{\mathrm{r}}^{2}+\mathrm{K}_{\mathrm{d}}^{2}+\mathrm{K}_{\mathrm{t}}^{2}=1
$$

For each experiment, the water level time series are measured using 3 wave gauges in front of the FCB. The water level data are sampled at a rate of $10 \mathrm{~Hz}$. All experiments run for a period of 12 minutes. DHI data acquisition software, [10], is used for data acquisition and stored in different files for further analysis. For quality control, the wave gauges are calibrated at the beginning of each set of tests.

Unsuitable positioning of the wave gauges affects the analysis results. Position of the gauges mainly depends on the wave parameters (wave period and wave length). Therefore, numerical investigations followed [7] have resulted in a number of appropriate choices for internal gauge distances relative to the wave length. The best ones being:

$$
\frac{\Delta l_{12}}{\Delta l_{23}}=\left\{\begin{array}{l}
1 / 10 \\
3 / 10
\end{array}\right.
$$

Where:

$\Delta \mathrm{l}_{12}$ is the internal gauge distance (between gauge 1 and 2)

$\Delta \mathrm{l}_{23}$ is the internal gauge distance (between gauge 2 and 3 )

Dimensional analysis was discussed in detailed in [8]. For this study new approach and its specific tests program we concluded the following relation for $K_{t}$ and $\mathrm{K}_{\mathrm{r}}$ with dimensionless parameters:

$$
\mathrm{K}_{\mathrm{t}}, \mathrm{K}_{\mathrm{r}}=\mathrm{f}\left(\mathrm{B} / \mathrm{L}, \mathrm{h} / \mathrm{d}, \mathrm{R} / \mathrm{H}, \mathrm{p}_{\mathrm{o}} / \rho g h, \mathrm{E} / \mathrm{p}_{\mathrm{m}} \mathrm{gh}, \rho_{\mathrm{m}} / \rho, \varepsilon / \mathrm{h}, \mathrm{H} / \mathrm{gT}^{2}\right)
$$

Where, $p_{0}$ : container internal pressure, $\rho$ : water density, $\rho_{\mathrm{m}}$ : Rubber material density, $\mathrm{E}$ : material Young modulus, B: Model width, $\varepsilon$ : material thickness. (E/pmgh, $\rho_{\mathrm{m}} / \rho$, and $\left.\varepsilon / \mathrm{h}\right)$ are insignificant in the practical range of application as it kept constant. In the following figures (13) to (18), the output of wave flume tests on moored model\#1 is arranged as follows:

Transmission coefficient; $\mathrm{K}_{\mathrm{t}}$ : Fig. (13) shows the relation between $\mathrm{K}_{\mathrm{t}}$ and $\mathrm{B} / \mathrm{L}$ (where $B$ is the model width and $L$ is the wave length) at different water levels expressed as $\mathrm{h} / \mathrm{d}$ (where $\mathrm{h}$ is the model height and $\mathrm{d}$ is the water depth). Fig. (14) shows the same output data but presented as the relation between $\mathrm{K}_{\mathrm{t}}$ and wave steepness $\mathrm{H} / \mathrm{gT}^{2}$ at same different $\mathrm{h} / \mathrm{d}$ values. The same analysis approach was applied for

Reflection (Figs.15 and 16) and dissipation coefficients (Figs.17 and 18). We noticed that $\mathrm{K}_{\mathrm{t}}$ does not change significantly with $\mathrm{B} / \mathrm{L}$ at $\mathrm{h} / \mathrm{d}=1.0$ and 1.2 but increased with $\mathrm{B} / \mathrm{L}$ at $\mathrm{h} / \mathrm{d}=0.85$; i.e, submergence condition. At $\mathrm{B} / \mathrm{L}=0.15$, almost the three water levels showed same $\mathrm{K}_{\mathrm{t}}=0.50$. Also, $\mathrm{K}_{\mathrm{t}}$ is almost the same for different $\mathrm{H} / \mathrm{gT}^{2}$ except at $\mathrm{h} / \mathrm{d}=0.85$ where it decreased with increasing wave steepness. 
With respect to reflection coefficient; $\mathrm{Kr}$, its value decreased with increasing $\mathrm{B} / \mathrm{L}$ and $\mathrm{H} / \mathrm{gT}^{2}$ as shown in Figs. (15) and (16) respectively. Submerged FCB ( $\left.\mathrm{h} / \mathrm{d}=0.85\right)$ gives lower $\mathrm{Kr}$ and subaerial one gives higher values. When studying dissipation coefficient, it was found that the model with water level condition $h / d=1.0$ gives higher value for $K_{d}$ which increases with increasing both $\mathrm{B} / \mathrm{L}$ and $\mathrm{H} / \mathrm{gT}^{2}$ to reach about 0.85 . In fact, at low $\mathrm{B} / \mathrm{L}$ and $\mathrm{H} / \mathrm{gT}^{2}$, submerged model gives almost same $\mathrm{K}_{\mathrm{d}}$ as the model with $\mathrm{h} / \mathrm{d}=1.0$.

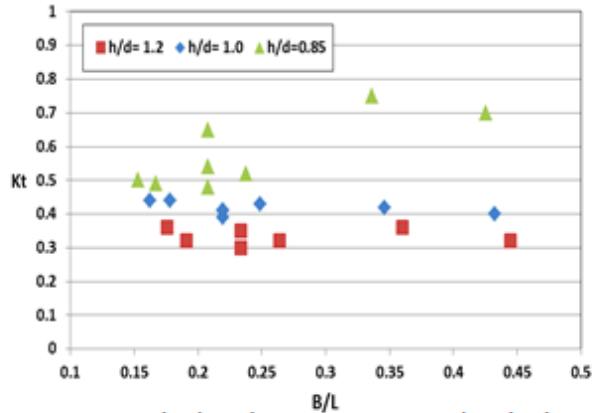

Fig. 13. Relation between $\mathrm{Kt}$ and relative FCB width at different relative depth

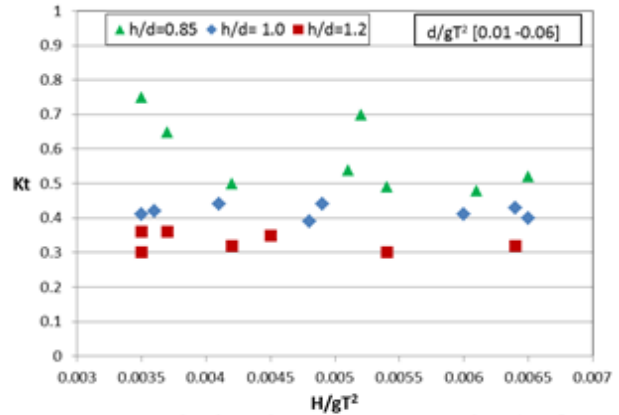

Fig. 14. Relation between $\mathrm{K}_{\mathrm{t}}$ and $\mathrm{H} / \mathrm{gT}^{2}$ at different relative depth

As given in table (3), some runs have been done under mooring conditions. As described, one mooring line was arranged to prevent the model excursion towards incoming waves direction. The force cell measured the tension force along each run. Maximum value is considered for the analysis and divided by net model immersed weight (total weight-uplift force) to drive a relative force; Fr [\%]. Fig. (19) shows the relative mooring force against relative model width at different water levels conditions. As shown the force Fr decreases as B/L ratio increases which means that model with higher B/L ratio is more stable and needs a less external mooring to keep it in position. Model at subaerial condition needs smaller mooring force due to its small buoyancy.

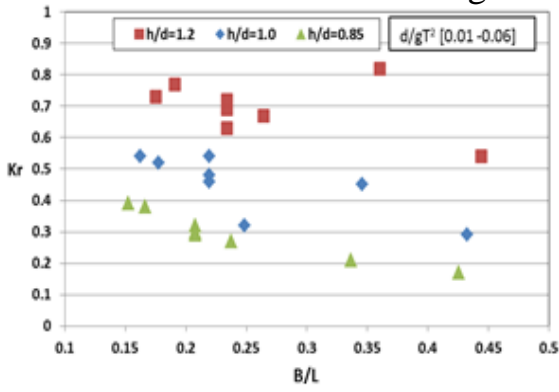

Fig. 15. Relation between $K_{r}$ and relative FCB width at different relative depth

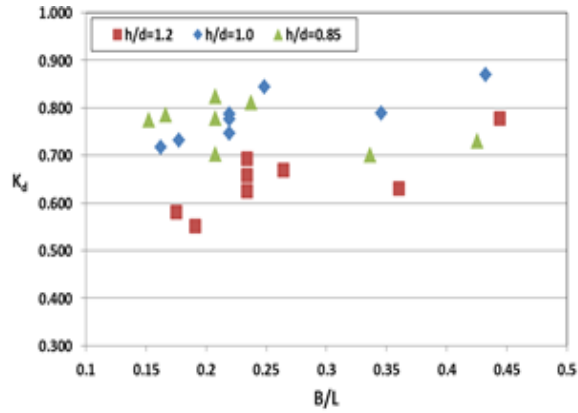

Fig. 17. Relation between $\mathrm{K}_{d}$ and relative FCB width at different relative depth

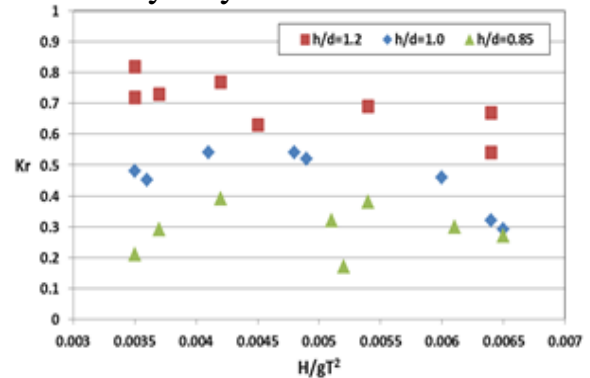

Fig. 16. Relation between $\mathrm{K}_{\mathrm{r}}$ and $\mathrm{H} / \mathrm{gT}$ : different relative depth

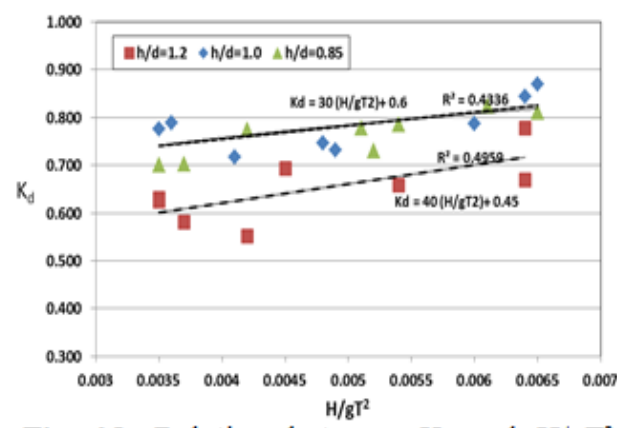

Fig. 18. Relation between $\mathrm{K}_{d}$ and $\mathrm{H}_{/} \mathrm{gT}^{2}$ at different relative depth 


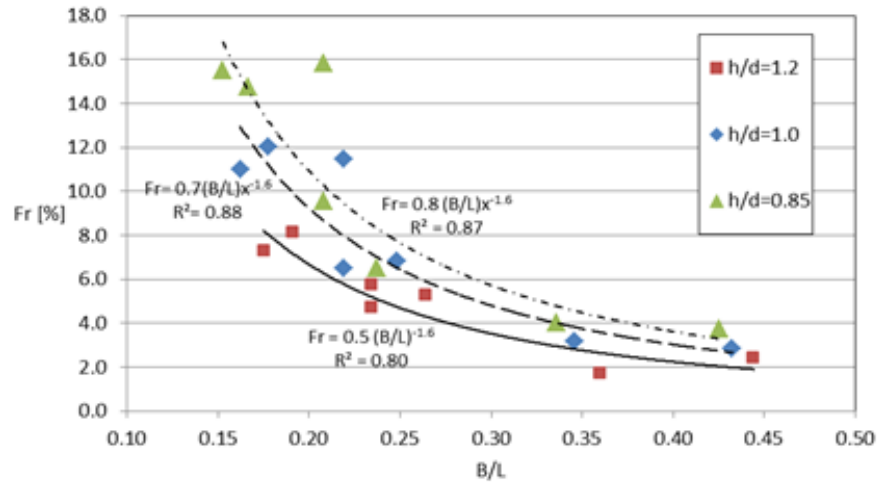

Fig. 19. Relation between Relative mooring force; Fr and relative FCB width at different relative depth

As given in table (3), only three runs have been done for the FCB without mooring (free seated). Fig. (20), indicates the relation of $K_{r}$ and $K_{t}$ with wave steepness at different water level conditions. In general, both coefficients decrease with increasing wave steepness. Average $\mathrm{K}_{\mathrm{r}}$ and $\mathrm{K}_{\mathrm{t}}$ values, within the tested wave parameters, is 0.50 and no excursion where noticed.

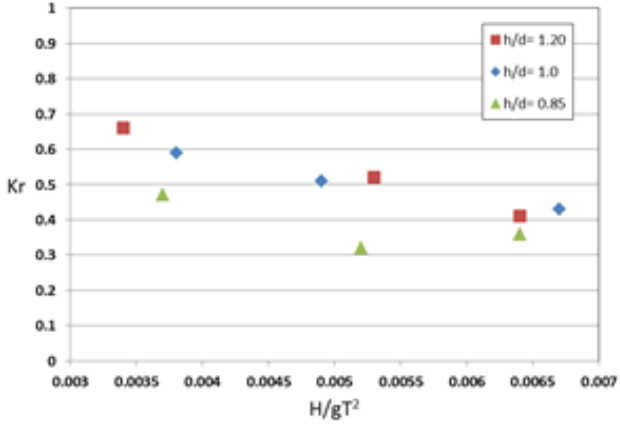

(a)

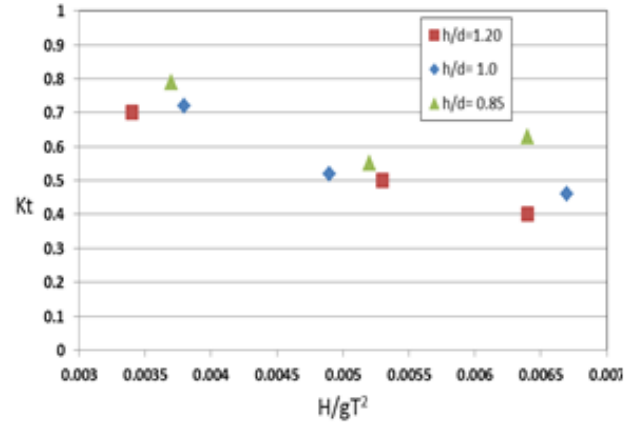

(b)

Fig. 20. Relation between $\mathrm{K}_{\mathrm{r}}$ and $\mathrm{K}_{\mathrm{t}}$ and $\mathrm{H} / \mathrm{gT}^{2}$ at different relative depth [Non-moored condition]

In the following figure (21), the basin tests results were analysed and presented as the relation between $K_{t}, K_{r}$, and $K_{d}$ and $B / L$ under different water levels conditions. In general $\mathrm{K}_{\mathrm{d}}$ increases with increasing $\mathrm{B} / \mathrm{L}$ value at different water levels. Also, $\mathrm{K}_{\mathrm{d}}$ for submerged conditions $(\mathrm{h} / \mathrm{d}=0.85$ and 1.0$)$ is higher than subaerial condition. In all cases, No model excursion was noticed.

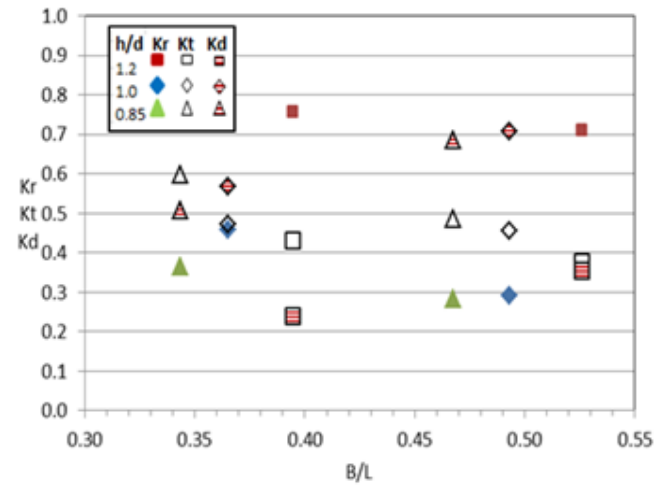

Fig. 21. Relation between $(\mathrm{Kr}, \mathrm{Kt}$, and $\mathrm{Kd})$ and relative $\mathrm{FCB}$ width at different relative depth- Basin Tests

Flexible container breakwater can be made from different flexible materials. For field applications, the most durable material should be selected according to the site specific 
environmental conditions and the application purpose (temporary or permanent). In this study, as explained earlier, two different materials have been used in different facilities; wave flume and basin. The scale and some wave parameters were kept the same, however, not only the model material is different but its width also (refer section 3). Fig. (22) shows comparison between the flume and basin tests with respect to the relation between wave dissipation coefficient; $\mathrm{K}_{\mathrm{d}}$, and relative depth; $\mathrm{h} / \mathrm{d}$. In this figure, only one wave Height and period is used with different water depth. The basin tests with model\#2 shows higher dissipation coefficient for submergence condition while almost same value noticed for subaerial condition.

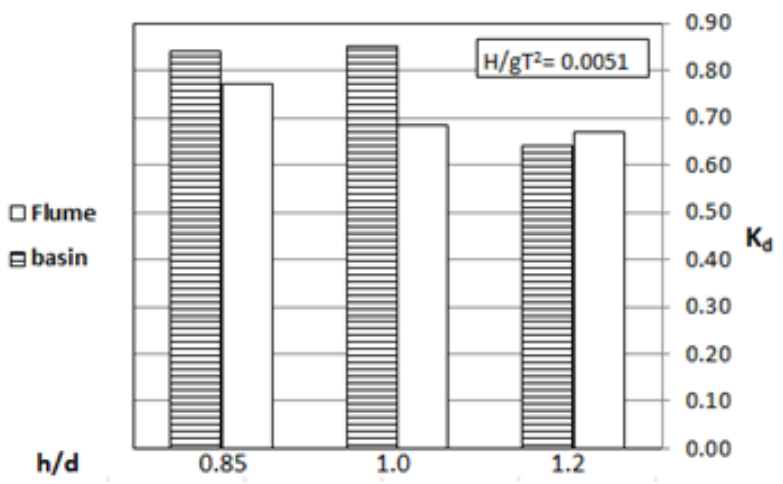

Fig. 22. Comparison between $K_{d}$ of flume model and basin model tests at different relative water depth

In the following figures, we present the comparison between FCB performance and some other traditional and non-traditional breakwaters. [4], studied in a wave flume the stability of interlocking D-block armor in a submerged trapezoidal breakwater. Transmission coefficient; $K_{t}$ is compared against wave steepness at almost same submergence ratios. We noticed that within same $\mathrm{H} / \mathrm{gT}^{2}$, the coefficient $\mathrm{Kt}$ is little less than D-block breakwater; Fig. (23).

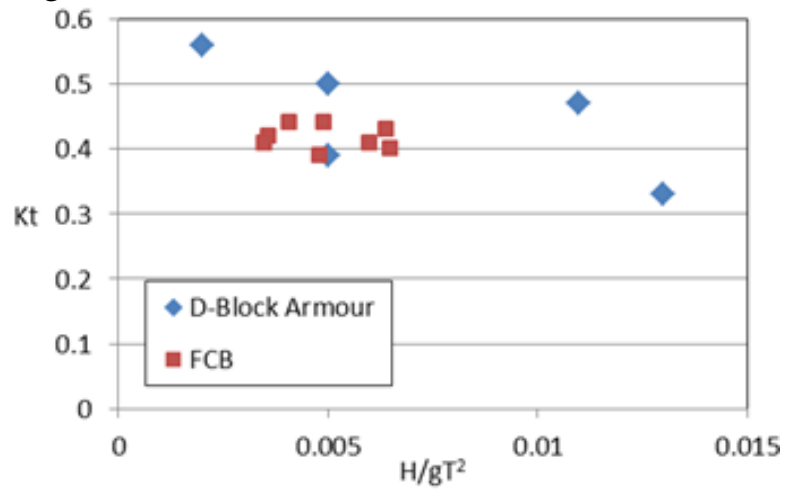

Fig. 23. Comparison between Kt of FCB model (flume tests) and Submerged Breakwater with Interlocking D-Block (adapted from [4])

[2] performed experimental tests in a wave flume on an array of perforated hollow hemispherical shaped artificial reefs (HSAR) used as a submerged breakwater. Regular and irregular waves were used. Almost two similar water depth ratios are used which represent submergence conditions. In Fig. (24), We noticed almost same relation trend between $\mathrm{K}_{\mathrm{t}}$ and $\mathrm{H} / \mathrm{gT}^{2}$ and still FCB shows little less wave transmission than HSAR submerged breakwater. 


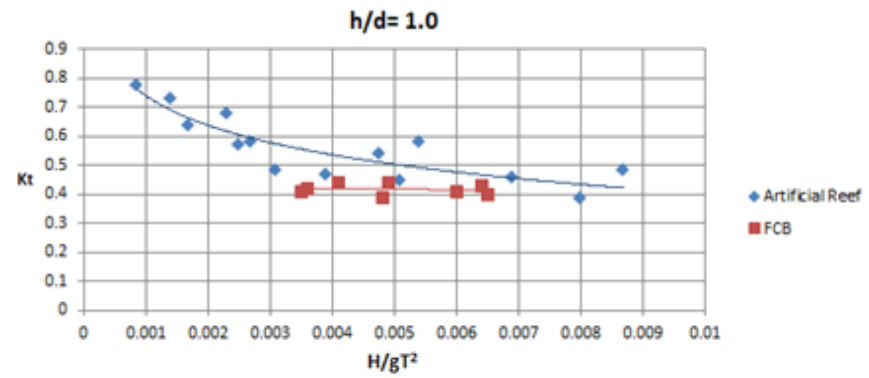

(a)

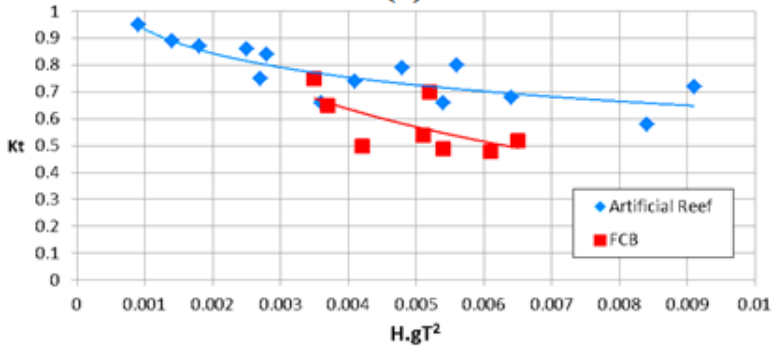

(b)

Fig. 24. Comparison between Kt of FCB model (flume tests) and submerged breakwater made of hollow hemispherical artificial reefs at different relative height; h/d (adapted from [2])

[8] studied experimentally a flexible submerged breakwater called "flexible mound", made of an elastic membrane (Fiber reinforced rubber) bag filled with water, for wave control in shallow water as an alternative to the conventional breakwater. It was compared against same shape but in rigid material. Their proposed system was tested also in field as submerged mound fixed on a frame which in turn was anchored to seabed. In this study, the submergence is expressed as $\mathrm{R} / \mathrm{h}$ as $(\mathrm{R})$ is depth of breakwater deck under water and (h) is water depth. R/h value is not exactly the same in FCB model study and in the flexible mound as shown in Figs. (25) and (26). Fig. (25), presents comparison between rigid and flexible mound for different $\mathrm{R} / \mathrm{h}$ and $\mathrm{R} / \mathrm{Hi}$ values. In this figure, we inserted our FCB tests data for $\mathrm{R} / \mathrm{h}=0.15$ and $\mathrm{R} / \mathrm{Hi}=0.50-2.0$. We noticed that the relation trend between $\mathrm{K}_{\mathrm{t}}$ and $\mathrm{B} / \mathrm{L}$ is almost the same in both models. The FCB model gives almost same $\mathrm{K}_{\mathrm{t}}$ value as the flexible mound in spite of different $\mathrm{R} / \mathrm{h}$ value as shown also in Fig. (26).

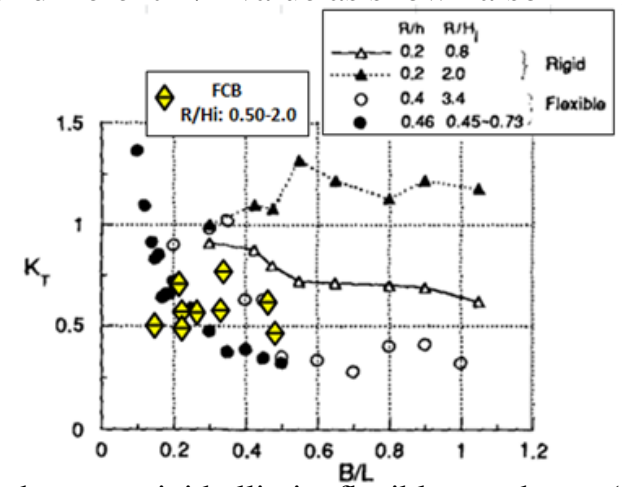

Fig. 25. Kt Comparison between rigid elliptic, flexible membrane (adapted from [8]), and FCB; $\mathrm{R} / \mathrm{h}=0.15$ (current study) 


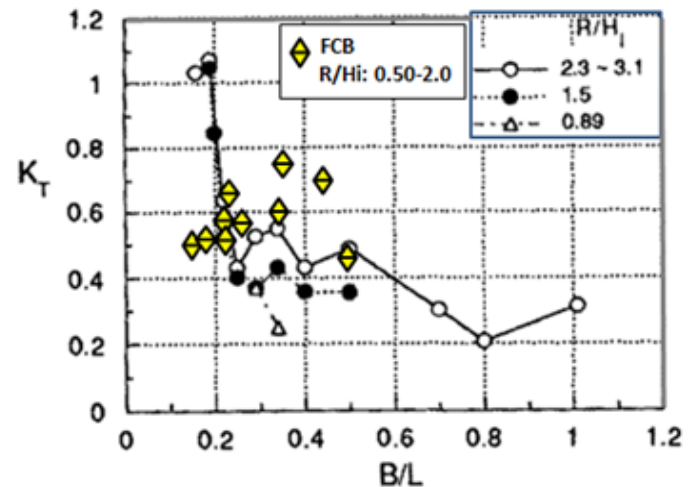

Fig. 26. $\mathrm{K}_{\mathrm{t}}$ Comparison between anchored flexible membrane $\mathrm{R} / \mathrm{h}=0.4$ (adapted from [8], and $\mathrm{FCB} ; \mathrm{R} / \mathrm{h}=0.15$ (current study)

In general, the FCB model tests with submergence condition especially at ratio $(\mathrm{h} / \mathrm{d}=1.0)$ resulted in better wave dissipation performance than the sub-aerial. From videos record for the model behaviour under waves we noticed that model oscillating under breaking/non breaking conditions add additional effect in reducing transmitted waves due to incidentradiated wave interaction. The model performance was more sensitive to wave period than wave height due to its ability to oscillate. [9] also have shown that his flexible mound can effectively dissipate waves even when the submergence ratio is greater than 0.4; i.e, $(\mathrm{h} / \mathrm{d}=0.6)$. It may be interpreted in same way as wave attenuation due to muddy bottom.

\section{Conclusions and recommendations}

Some experiments were carried out in a wave flume and basin on two types of flexible membranes as a breakwater. The following points could be concluded from the experiments results analysis;

- Filling the Flexible container with sediment slurry (about $40 \%$ sand) kept its surface flexible to enhance wave attenuation due to breaking and incident-radiated wave's interaction.

- Within this study program, the FCB can be stable free seated condition when it is subaerial under waves height and period, $\mathrm{H}_{\mathrm{s}}=1.50 \mathrm{~m}$ and $\mathrm{T}_{\mathrm{p}}=5.5 \mathrm{~s}$ when its bottom contact width is about 0.55 of the FCB width and under prototype waves height and period, $H_{s}=1.9 \mathrm{~m}$ and $\mathrm{T}_{\mathrm{p}}=7.0 \mathrm{~s}$ when its contact width ratio is 0.90 .

- The bottom contact width is affected with the FCB fabrication material and filling water quantity (internal pressure). The tested model\#2, with external geotextile layer was stable under the tested wave and filling conditions.

- In wave flume tests, the FCB needs to be moored from one side to prevent it excursion towards the wave coming direction. Models with $\mathrm{B} / \mathrm{L}=0.45$ needs maximum mooring force about $2 \%$ of its net weight when be under subaerial conditions. Submerged models, especially when $\mathrm{h} / \mathrm{d}=1.0$, shows higher wave dissipation than subaerial models. This was due to combined impact of breaking and incident-radiated waves interactions.

- The dissipation coefficient, with the tests program, reached to $80 \%$.

- The FCB material is expected to play a good role in the stability with respect to its friction coefficient with seabed, oscillating features under waves, and the system service life. Performance of other materials such as extremely durable, vinyl-coated polyester may need to be studied in future.The FCB is characterised with some advantages; more compact compared to conventional breakwaters, causes no 
sacrifice to the scenic value of the waterfront, suitable for wide range of seabed conditions specially weak soil, and fast and simple erection and dismantling process.

- The FCB failure mode is not harmful and not costly (just rolling/excursion away) under extreme conditions, affordable cost, and environment friendly. The proposed method of application starts with spreading the FCB units with defined lengths. Considerable overlaps to be considered for successive segments. Then, use a hydraulic Submersible Pump to discharge water sand mixture to inflate the container with predefined sand percentage.

- According to site conditions, the FCB material, and results of this studythe FCB may be free seating or require moored belts to seabed at interval distances. It may serve as submerged or subaerial breakwater according to the site environmental conditions (it may work as subaerial and submerged breakwater in high tidal range zones).

\section{Acknowledgment}

The author would like to thank KOC-marine services team in Kuwait and SCA-Research center team in Egypt for support to undertake this research and providing the research facilities.

\section{List of symbols}

B: Breakwater Crest Width [m]

b: Tube contact surface width [m]

d: Water depth [m]

h: Breakwater height $[\mathrm{m}]$

$\mathrm{R}$ : Distance between water surface and breakwater deck [m]

$\mathrm{R} / \mathrm{d}$ : Submergence ratio [-]

$\mathrm{H}_{\mathrm{s}}$ : Significant wave height $[\mathrm{m}]$

Tp: Peak wave period [s]

$\mathrm{H}_{\mathrm{i}}$ : Incident wave height [m]

$\mathrm{H}_{\mathrm{r}}$ : Reflected wave height [m]

$\mathrm{H}_{\mathrm{t}}$ : Transmitted wave height [m]

$\mathrm{K}_{\mathrm{r}}$ : Wave Reflection coefficient [-]

$\mathrm{K}_{\mathrm{t}}$ : Wave Transmission coefficient [-]

$\mathrm{K}_{\mathrm{d}}$ : Wave Dissipation coefficient [-]

$\mathrm{E}_{\mathrm{i}}$ : Incident wave energy [Joule]

$E_{\mathrm{d}}$ : Dissipated wave energy [Joule]

$\mathrm{E}_{\mathrm{t}}$ : Transmitted wave energy [Joule]

$\mathrm{E}_{\mathrm{r}}$ : Reflected wave energy [Joule]

$\mathrm{H} / \mathrm{gT}^{2}$ : Wave steepness [-]

d/gT2: Relative water depth [-]

\section{REFERENCES}

[1] Andrew B., Abel M., and Chris V. (2010): Modeling \& Testing of Inflatable Structures for Rapidly Deployable Port Infrastructures, Ship Systems Integration \& Design Department Technical Report, NSWCCD-CISD-2010/010

[2] Armono, H., Hall, K.R. (2003): Wave transmission on subemerged breakwaters made of hollow hemispherical shape artificial reefs, Canadian Coastal Conference proceeding.

[3] Gade, H.G. (1957): Effects of a non-rigid impermeable bottom on plane surface waves in shallow water: Ph.D. Thesis, Texas A\&M University, 35p.

[4] Hamdani, Bambang Trihatmodjo, and Suharyanyo (2015): Wave Transmission on Subemerged Breakwater with Interlocking, International Refereed Journal of Engineering and Science (IRJES), Volume 4, Issue 6 (June 2015). 
[5] Jiang, F., Mehta, A.J. (1996): Mud banks of the southwest coast of India V: Wave attenuation, J. Coastal Res., 12(4), pp. 890-897

[6] Mehta, Ashish J. (2014): An introduction to hydraulics of fine sediment transport, Advanced series on ocean engineering, volume 38, Word Scientific Publishing Co, Singapore, ISBN 978-981-4449489

[7] Mansard, I.p.D. and E.R. Funke (1980), "The Measurement of Incident and Reflected Spectra using a Least Squares Method". Hydraulics Laboratory Technical Report LTRHY72. National Research Council.

[8] Tanaka, M., T., Ohyamall, Kiyokawa ,T. and Omata, A. (1992): Characteristics of Wave Dissipation by Flexible Subemerged Breakwater and Utility of The Device, Conference on Coastal Engineering which was held in Venice, Italy, October 4-9, 1992.

[9] Tanaka, M., Mitsumata, M., Ohyamall, T., Kiyokawa, T., Uda, T. and Murai, Y. (1987): Experimental study on wave control by a flexible subemerged dike, Proceeding of the 34 th Japan Conference on Coastal Engineering, JSCE, PP. 492-496.

[10 DHI Wave Synthesizer (2013): Data analysis, User Guide 


\section{تقييم تخفيف الأمواج بواسطه حاجز أمواج من حاويه مرنه}

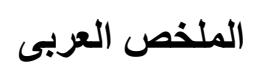

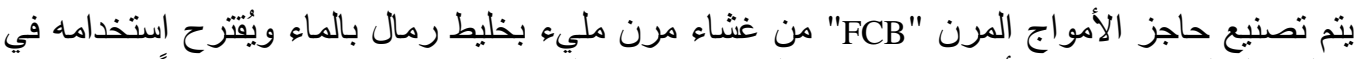

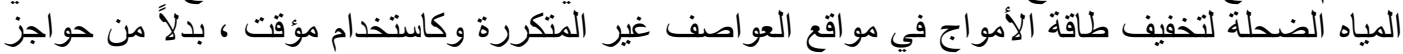

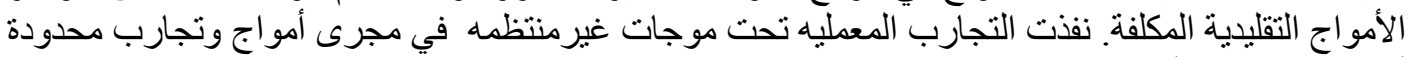

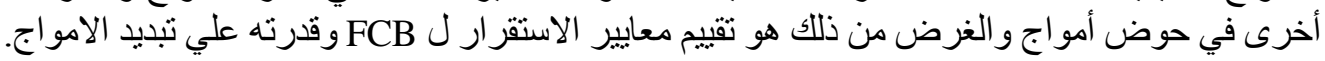

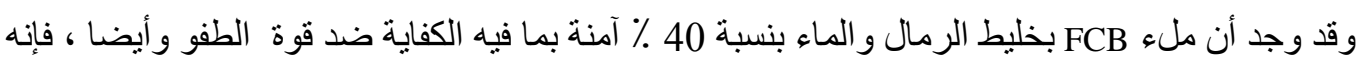

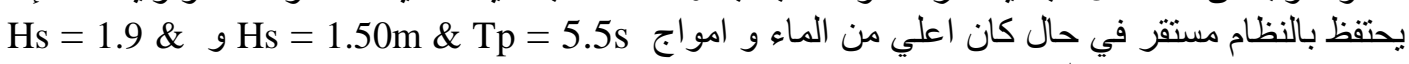

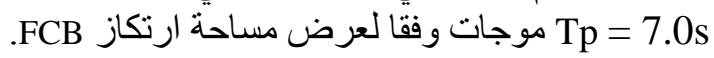

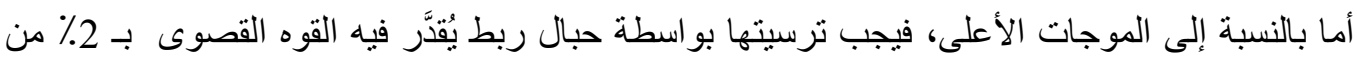

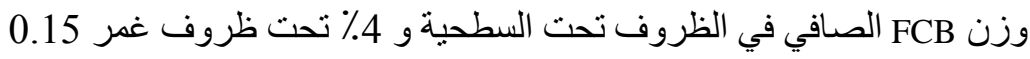

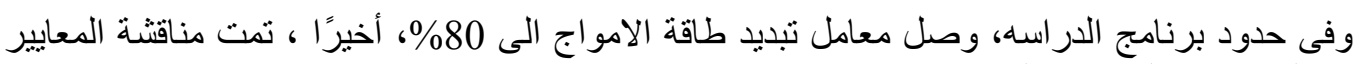

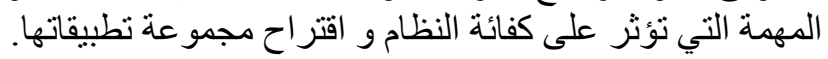

